\title{
Contextualizing History in Hungarian Films of the New Millennium
}

\section{Clara Orban}

\begin{abstract}
Hungarian films produced after the year 2000 build on the historical reality of the fall of communism and anticipate, or come to terms with, entry into the European Union. This article will explore six films that deal with history through multiple perspectives to dramatize the dynamic between historical events and human responses to them. These films reference history, or efface it, as a way of problematizing the relationship between human behavior and history. Colossal Sensation [Világszám-Dodó és Naftalin] (2005) and Children of Glory [Szabadság, szerelem] (2006), for example, examine Hungarians' moments of defiance during the 1956 uprising but shape historical events to fit human constructs. Contemporary history provides satire of rising capitalism in The District! [Nyócker!] (2005) whose plot weaves historical figures into a modern rendition of Romeo and Juliette. Miracle in Krakow [Csoda Krakkóban] (2004) also presents a book as its central metaphor, and, like The District!, the book allows some of history's uglier moments to be erased. Béla Tarr's Werkmeister Harmonies [Werkmeister harmóniák] (2000) and Nimród Antal's Control [Kontroll] (2003), films without overt historical markers, provide allegorical visions of societal unrest that can be read as allusions to millennial concerns.
\end{abstract}

Keywords: history, millennium, cinema, Hungary, the end of history

Biography: Clara Orban is professor of French and Italian at DePaul University, and chair of the Department of Modern Languages. She has published seven books, numerous book chapters, articles, and papers on surrealism, futurism, language pedagogy, AIDS literature, sports, TV, Italian film, and Hungarian film. She is also a certified sommelier and teaches a geography course based on wine at DePaul. Her most recent book, Wine Lessons: Ten Questions to Guide Your Appreciation of Wine (2012) is in its second edition. The Illinois Wine and Wineries: the Essential Guide came out in 2014.

Even among the group of former Soviet satellite countries whose histories, especially during the twentieth century, proved turbulent, Hungary's historical trajectory in the last century or so has seemed particularly frenetic. As Péter Hanák puts it, Hungary experienced "no less that nine turning points in the first 70 years of the twentieth century," revolutions, uprisings, loss of national territory, occupation, wars, colonization, re-integration, etc. This small, landlocked country of about 10 million people weathered many seismic shifts in political orientation in the span of a few generations. From an imperial society with bourgeois values, consumer culture, and many of the vestiges of democracy (within the context of fin-de-siècle Europe) to the rupture of these societal 
Orban, Clara. "Contextualizing History in Hungarian Films of the New Millennium." Hungarian Cultural Studies. e-Journal of the American Hungarian Educators Association, Volume 6 (2013): http://ahea.pitt.edu DOI:

parameters during Soviet rule, back to full integration, certainly could make the case that Hungarians' flexibility was tested to the limits. History and politics, therefore, for Hungarians appear not only as scaffolding under which events construct themselves but rather as the very markers of existence and identity.

The new millennium arrived within the decade and half timeframe during which Hungary moved from communism to membership in the European Union. This time period also brought a major shift to Hungarian cinematic output. As John Cunningham notes, the need to compete in an increasingly open market against foreign films, subsidies that did not keep pace with inflation, and other factors affected film production and even the subject matter and tone of Hungarian films (142144). Catherine Portuges provides a review of Hungary's filmic trajectory during these years. Prior to 1989 , many Hungarian films evoke loss: private, political and collective. In the post socialist period, "these frequently bitter dramas enact protagonists of undoubted spirit and energy, whose dreams of freedom and hopes for a better life mirrored the seismic changes underway in the region" $(2007,526)$. "Millennial films," that is films produced within a few years of the new millennium, would also be products of this historical context of extreme political changes with intense societal implications. ${ }^{1}$ Explicit references to historical moments, or avoidance of obvious historical references, allow filmmakers to comment on how history has impacted Hungary in such a short span of time. In many films, historical events provide realistic backdrops to the narrative and character development. Conversely, there are also several recent Hungarian films that specifically avoid mentioning historical events and create a sort of ahistorical present in which characters must survive, grow, or perish.

Films which explore historically relevant moments, which evoke mythical pasts, or which include references to recognizable historical figures abound in Hungary during the first few decades of the new millennium. Portuges reminds us that recent Hungarian cinema has been rich with explorations of history at a time when Hungary was undergoing historical change: "The country's accession to the European Union as one of its first East European members, took place in May 2004, during a period when the sixtieth anniversary of the deportation of nearly a half million of the country's Jewish population was also being commemorated" $(2005,122)$. The historical events often refer to actual, traumatic or exhilarating moments of Hungarian twentieth century history. In her article outlining the many changes Hungarian cinema has undergone since the end of Soviet rule, Portuges notes that in the immediate post-Soviet era and beyond, a certain number of films tend towards memorializing Hungarian history and culture, often foregrounding Hungary's most controversial and provocative issues such as the "contested terrain and unresolved questions pertaining to the revolution of 1956" (2013, 104-5).

The 1956 uprising provides the central backdrop to two millennial films I will explore: Colossal Sensation (Vilaszam! Dodo és Naftalin 2005) and Children of Glory (Szabadság, szerelem

\footnotetext{
${ }^{1}$ When discussing Ildiko Enyedi's films, Portuges provides a thematic vision, noting that "millennial concerns in 2000, widely reported in the media, ranged from a heightened sense of uncertainty, an intensified fear of the unknown, a quest for internal connection and resurgence of religious mysticism, this accompanying doomsday fantasies predicting the end of the world" $(2007,528)$. Portuges' analysis creates a theoretical paradigm for millennial concerns that then translates into the film she examines. In this article, I intend the term millennial in the strictest sense, that is films that were released shortly after the arrival of the new millennium. The six films selected cover only six years, thus we can make comparisons and conclusions among them assuming they come from a very similar historical context.
} 
Orban, Clara. "Contextualizing History in Hungarian Films of the New Millennium.” Hungarian Cultural Studies. e-Journal of the American Hungarian Educators Association, Volume 6 (2013): http://ahea.pitt.edu DOI:

2006). In both films, diegetic historical events are reinterpreted to fit the human framework of the films' characters. Characters survive events by calling on behavioral, societal, or psychological strategies that then become over-arching filmic themes. In two other films, The District (Nyóckér! 2005) and Miracle in Krakow (Csoda Krakkoban 2004), a book shapes the filmic narrative, and history is either rendered comic through reduction ad absurdum or erased as though the film's literary backdrop allowed historical reality to dissipate. In both films, history's erasure allows the films to gloss over ethnically charged historical realities, hatred of minorities in the former film, or anti-Semitic genocide in the latter. The absence of diegetic history in the final two films we will explore creates allegorical landscapes seemingly outside history. The elimination of specific historical dates and places to contextualize the narrative and multiple allusions to the allegorical possibilities present in each film, however, allows the viewer to search for allusions to historical realities. Béla Tarr's Werkmeister Harmoniak (2000) shrouds events outside history to explore moments of societal and cultural strife. Nimród Antal's Kontroll (2003) provides an allegorical vision of societal unrest in the present experienced by characters who have given up searching for ideals. In both the latter films, the viewer inevitably transposes the historical context of the years bridging the millennium onto the narrative because of the heavily allegorical construction.

Francis Fukiyama's much debated concept of the "end of history" could provide an overarching construct for this exploration of millennial films. Fukiyama acknowledges that his work has often been misinterpreted, because his notion of "history" was taken out of context. He says that "what I suggested had come to an end was not the occurrence of events, even large and grave events, but History, that is, history understood as a single, coherent, evolutionary process." Fukiyama examines history's unfolding, and shows through an exploration of modern natural science that we may have arrived at the point of satisfaction which was assumed as the endpoint of history in Hegelian or Marxist linear historical projections. Once humans had achieved a satisfactory state (Fukiyama posits liberal democracy, which seemed to flourish as he was creating his theory, as that state) there would be no further need for development of underlying principles (xii). In that sense, then, historical progression would no longer be necessary. While this assessment of Fukiyama's hotly debated thesis is by necessity very brief, the parameters of his thesis give a framework for the trajectory we will explore in the six Hungarian films from the early years of the new millennium. Historical events, when present in these films, are given meaning only within frameworks of human psychology or behavior. In some films, historically identifiable events disappear, allowing ample space for allegory to point the viewer back to the historical context in which the films were produced. History may indeed be at an end in these films, as Hungary was launching into uncharted historical territory. The general outline of Fukiyama's theory could be a useful way to look at history as interpreted in these films, although the details of his political and scientific proposals remain outside the scope of the present study.

His 2005 film, Colossal Sensation, allowed Hungary's famed comic actor Robert Koltai to explore the absurdity of politics. Twin boys are born to a clown father who puts them into an act as "Dodo" and "Naftalin." They are often mistaken for one another, and from an early age they feel each other's pain, as though they were one person. When in one act, Naftalin smashes the Commissar's watch as the Commissar helplessly gazes from the audience, Dodo goes to jail instead of Naftalin because of a mix-up. Dodo spends many years in prison while Naftalin continues his life outside. Relegated to prop man of a Budapest theater, Naftalin must go on stage one night to take the place of a missing actor. In the heat of the October 1956 uprising, instead of saying his line correctly, "Join Them," he says "Hang Them." This triggers a reaction in the audience which begins to chant "Russians Go Home," and we are to believe Naftalin becomes a leader of the uprising. In 
Orban, Clara. "Contextualizing History in Hungarian Films of the New Millennium.” Hungarian Cultural Studies. e-Journal of the American Hungarian Educators Association, Volume 6 (2013): http://ahea.pitt.edu DOI:

this film, historically realistic moments are personalized as they reinforce the brothers' connection. The audience's denouncing the Russians in the theater echoes chants that erupted during the uprising.

Naftalin uses his newfound power to rescue Dodo from jail by bringing a Soviet tank to the prison which he managed to commandeer from two Asiatic Russian soldiers cruising the countryside. The lost soldiers had been told about the Suez Canal and Naftalin finds them searching for it on the map, unable to confirm the location of the Suez conflict because their radio is dead. This allows Naftalin to trick them into believing Suez is just up the road; they all ride the tank towards the prison while the Russians believe they are pointed towards Suez. Of course, one of the reasons that world attention was diverted during the Hungarian uprising, and that Western countries failed to intervene, was the eruption of the Suez crisis during those days in 1956. In this film, the Suez crisis becomes a pretext for resolving the brothers' separation dilemma. History provides a remedy to move these characters forward in the narrative.

The pair continues to live out their existence in Hungary, and the film ends in the 1970s with the brothers still trying to get the better of the system that has since forgotten the now old men. In the final scene, they steal a minibus parked at a rest stop and go into the sunset on a joy ride, bonding as only twin siblings can.

Historical events during communist times in this film just happen, seemingly without reason. Revolutionary "leaders" fall into their roles without having any idea of what is happening, as does Naftalin during that fateful evening at the theater. Dramatic events happen when people encounter language barriers or are lost in unfamiliar territory, as exemplified by the tank episode. The twins seem to have clowned their way through history; historical events appear random, as though they were pratfalls from a clown's act. Perhaps in this film Koltai shows us the randomness of history, of glory, and of defeat. In a film which references one of the seminal historical events of recent collective Hungarian memory, Koltai brings those events into human perspective through this comedic lens. These clown brothers recall Samuel Beckett's Waiting for Godot, where Vladimir and Estragon, two clown friends, see the randomness of events as an indication of our universal solitude. Koltai's twin clowns who drive off into the sunset in their stolen minivan, have only each other in the end, just as the protagonists in Beckett's play realize that all they have is one another, because God(ot) is not coming. Koltai shows us a historical moment without the grandiose posturing of those who would "make history," leaving instead room for the randomness of a great cosmic joke. In this film, still constructed on the basis of historically identifiable events and therefore before "the end of history," we already witness history succumbing to parodic treatment, a mirror to human comedic impulses.

Children of Glory is a sports film tangled with a love story taking place against the backdrop of the Hungarian 1956 uprising. As was the case for Koltai's film, here too historical events are demystified. Children of Glory uses the famed match between the Hungarian and U.S.S.R. water polo teams at the Melbourne Olympics in the uprising's aftermath to stage the story of two best friends, Tibi and Karcsi, teammates and rivals for Viki's hand. Historically, this match was truly a defining moment in Hungary, felt as a symbolic moment of resistance, a sort of "uprising in sports." Events in the film parallel fairly accurately the historical events leading up to the "Blood in the Water" match, still considered the bloodiest Olympic encounter. During the fall days of the uprising, the Hungarian team practiced in the hills around Budapest, and was subsequently taken to Czechoslovakia by train. The December 6 Olympic match took place during the post-uprising crackdown. In the film, during the uprising when it seems the Russians have left, Karcsi rejoins his team as they depart for Melbourne, having previously left to fight alongside Viki and her fellow 
Orban, Clara. "Contextualizing History in Hungarian Films of the New Millennium.” Hungarian Cultural Studies. e-Journal of the American Hungarian Educators Association, Volume 6 (2013): http://ahea.pitt.edu DOI:

revolutionaries. The tanks come back, however, and the team helplessly watches from the TV in their Australian hotel. In a sequence of shots that juxtaposes what is going on in Australia with events in Budapest, Viki is captured, tortured and killed, while the Hungarians go on to beat the U.S.S. R. and win gold. As Viki is taken to the firing squad in Budapest, other female prisoners softly sing the Hungarian anthem. The scene cuts to the victory podium in Melbourne where athletes hear the anthem. Ironically, several of the team members have already accepted offers from Western teams and plan to defect after the Olympics.

In Colossal Sensation, historical events become pretexts for farcical elements, consonant with the personalities of the twin clown protagonists. In Children of Glory, revolutionary zeal and defiance parallel familial rebellion. Society's upheaval happens within the context of, and mirrors, individual family struggles between quasi-siblings, parents and children. Importantly, the character that remains unwavering in her revolutionary zeal, and the one whose death because of her beliefs receives the most narrative space, has no familial ties left. Viki, orphaned when her parents were killed by AVO secret police, embraces the uprising. She is among the leaders in the university student group organizing the demonstration that breaks out. She no longer needs to rebel against familial constraints and is therefore free to enter the historical flow of events. Viki is the character who develops the least during this film, staying true to her revolutionary ideals formed long before when her parents were murdered. Her lack of family ties allows her to embrace her duty to the patria, substituting the father figure she lost with the promise of a new nation.

Karcsi's character, however, changes when influenced by historical events. From a devilmay-care playboy he becomes a revolutionary, initially to please his love interest. By the end of the film he represents national pride during the match and after. Karcsi, attracted to Viki, hesitates to join the uprising for fear of compromising his place as the star of the water polo team. This leads to a quasi-sibling rivalry when he and Tibi compete for Viki's attention. Throughout the early part of the film the two water polo players are inseparable, but their interest in Viki frays that relationship. Before Karcsi's interest in Viki leads him to join the revolutionary effort, he and Tibi remain aloof to historical events, literally engulfed by them. In one scene they are surrounded by crowds marching on the parliament, and, although not immune to the fervor of their compatriots, the water polo team comes first for the two men. Once Karcsi, influenced by Viki, joins the fight, he and Tibi become estranged; the quasi-familial ties are broken when the patria replaces brotherhood.

Karcsi also lives an estrangement from his biological family as he intensifies his revolutionary involvement. At first, his mother shows resentment towards Viki, believing she alone is to blame for Karcsi's joining the fighting and quitting the water polo team. Karcsi's family resents Viki's intervention, as the water polo team represents a possible financial boon for the family. Parents in this film become impediments to characters embracing what the viewer is led to believe is their historical destiny. Besides the biological family's resistance, the team's coaches also present resistance to the players' joining the uprising. The team's coaches are portrayed as substitute parents, especially when the team is forced to move to the hills to practice and they serve in loco parentis. The team defies the coaches just as Karcsi defied his family, although the team does join the revolution by beating the enemy - in the Melbourne pool rather than on the Budapest streets. This, too, allows the characters to enter a historical series of events as protagonists, which becomes possible only when they defy their families, both biological and societal. Even more so than Colossal Sensation, Children of Glory's narrative moves through a series of historically accurate events in Hungary and in Australia. As was the case in Koltai's film, historical events are molded to human constructs and in some way subjugated to them. The Revolution, as a historical reality, 
Orban, Clara. "Contextualizing History in Hungarian Films of the New Millennium.” Hungarian Cultural Studies. e-Journal of the American Hungarian Educators Association, Volume 6 (2013): http://ahea.pitt.edu DOI:

projects onto familial uprisings of many types as human social units define and reconstruct the larger historical framework within which the characters exist.

Two films from the early years of the twenty-first century have a book as a structuring plot element. The existence of these artistic creations allows historical events and personages to become a backdrop for the larger erasure of societal tensions and tragedies. The District is an odd, edgy, animated satire of Romeo and Juliet. The star-crossed lovers, Ricsi and Julika, are a Roma youth and his love, a girl whose father is a pimp in the district. This film provides a multi-cultural panorama, a bildungsroman of sorts in the hip-hop Budapest of the new millennium. Children grow into adults under the supervision of lecherous grandparents, pimps and politicians of all nationalities.

The story's multiple layers involve Ricsi and Julika scheming with their equally "outsider" neighbors, an Arab and a Chinese boy, to find oil so they can get rich, since girls will only go with rich dudes according to Ricsi's grandfather. In this multiethnic district, ethnic tensions lie just under the surface among the inhabitants who taunt one another. The children occasionally confront one another on the playground and in the streets, egging each other on with slurs. Things change, however, when they hatch their scheme. Bored with their schoolwork, especially the literature class in which they are reading Shakespeare's play, getting rich quick becomes the focus of their afterschool attention. The young people create a time machine to go back to prehistoric Budapest so they can kill mammoths with a nuclear bomb provided by the Arab boy's "Uncle Osama." Over the millennia the decayed animals become the raw material for petroleum deposits under the "district" and once oil begins to flow, the kids get rich. However, forces of evil in the persons of George Bush, Colin Powel, Jacques Chirac, Tony Blair (initially dressed as the Star Wars character Darth Vader), Pope John Paul II, and Ariel Sharon, conspire to take the deposits away. World leaders have discovered the new oil and must eliminate their competition over these resources. However, the oil runs out and when it does, so does love. At the end of the film, despite a lack of physical obstacles to their love, Ricsi discovers Julika's budding lesbian tendencies and the pair remains separated.

While this film is certainly irreverent in its allusions to actual historical figures, their presence provides the catalyst for events. These worldwide political figures try to appropriate the economic gains of the dispossessed characters in the Budapest ghetto but are thwarted when the residents band together. This neighborhood, previously marred by ethnic friction, unifies only when intruders threaten the economic windfall the children produce. The District contains authority figures with little authority, and corrupt beat cops who perpetuate the gangsterism and profit from it. The world leaders, too, are portrayed as scheming charlatans. Political solutions are powerless to create better living conditions; only the inhabitants of the district can create their own laws and order. The District parodies contemporary historical figures but leaves them outside a historically realistic context.

The characters in The District do not go outside their small geographic area (even when they return to the prehistoric past, they are still in the district), where they are surrounded by the socioeconomic, racial, and ethnic "Other" in a constant state of barely concealed tension. However, capitalistic entrepreneurship will "unite" and eliminate enmities in this fable of contemporary underworld Budapest. Portuges suggests The District is typical of post-Soviet era films which provide a "multifaceted critical discursive debate on the reformulation of national identity and collective memory" $(2013,121)$. The viewer is aware of historical realities underlying the film, the enmity towards Roma, for example. Only lighthearted references are made to this ethnic difficulty as the film substitutes the fable of two rival families and two star-crossed lovers- the Capulets and Montagues become the Roma and the Pimps - for any in-depth investigation of ethnic tensions. In fact, in this fable, everyone ultimately gets along, for the sake of economic gain. Shakespeare's play 
Orban, Clara. "Contextualizing History in Hungarian Films of the New Millennium.” Hungarian Cultural Studies. e-Journal of the American Hungarian Educators Association, Volume 6 (2013): http://ahea.pitt.edu DOI:

here serves perhaps as a way to de-historicize this difficult ethnic reality since the presence of this fictional meta-narrative allows for the fictionalization of even the real historical personages who appear. In the end, the film's conclusion seems to suggest that capitalism will bring us all together as ethnically diverse neighbors work to get the most out of the multinational petroleum complex. In this new millennium version of Shakespeare's tragedy of two lovers fated to be separated forever, ethnic tensions can be overcome, even erased, to take advantage of rising capitalist possibilities.

Miracle in Krakow is set in the beautifully suggestive old Jewish quarters of Budapest and Krakow. In the film, a book, significantly titled The Silver Crown, becomes the pretext for characters reconnecting with their past, all the while erasing to some degree the reality of Eastern European Jews. Eszter, an art student in Budapest, comes to Krakow with a book she found in her grandfather's bookstore. She needs to retrieve the few missing pages to use the book to restore Jewish graves. Pyotr, who had met Eszter as a little boy in the Budapest bookstore, has the pages of the book he claims is a family heirloom. Significantly, these two characters must move away from Budapest to find the past, since identity has now become transnational. Poland, another former Communist state with a similar history of Jews and the War to that of Hungary, allows these characters to explore their multiple identities - Hungarian, Jewish, immigrant to Poland — and to create a new identity for themselves in the process. The book, and the graves it helps to restore, even bring the dead back to us as magical elements supplant historical realities. Pyotr not only can conjure his beloved grandmother back from the dead for a brief moment through a spell, but Eszter, who had left for Budapest, comes back to him in Krakow to be with him. In this subdued, nostalgic film, history is viewed through sepia tones and politics and history give way to individual memories.

While it is clear this film takes place within a fairly recent historical period given the costumes and the setting, constant visual references remind us of the past. Several scenes include characters dressed in period costumes for a masquerade street fair, thus blurring temporal parameters. Furthermore, the camera lingers on spaces that reference the past: old buildings, central town squares ringed with historical houses, cemeteries with old headstones, bookstores with old volumes on display, old synagogues, and so forth. References to specific historical moments surrounding the Nazi persecution of Jews in Hungary and Poland are erased in favor of ahistorical mystical or magical spaces. It is in the synagogue that Rabbi Levi manages to conjure up the dead grandmother, for example. He uses a dreidel, a child's spinning top - a popular toy in Jewish households especially during the winter festival of Hanukkah - to cast the magic spell. Bringing Jewish culture and people back to life, restoring or rescuing them, happens not through systematic evaluation and atonement for historical atrocities but rather by magic and children's games. When the damaged book is mended the physical traces of the dead, their gravestones, can be restored. Historical realities are erased, leaving the pages of a mended book to restore what has been lost.

More deeply than was the case in The District, the book in Miracle in Krakow allegorizes historical events. The reality of the disappearance of Jews from both Poland and Hungary is relegated to the periphery of the film. The miracle of the damaged book brought back to life allows for the dead, too, to be given the dignity of recognition as the tombs are restored. Jews do exist in this film: as cosmopolitan, secular young people; as elderly and dead people; or simply as markers on long-forgotten graves. The film references Jewish life through children's games such as the dreidel as though it were part of the characters' past but not their future. The grandmother too is resurrected when a spell is conjured to bring her back for a brief moment, as though childhood could purify the past. Glossing over historical details restores unity, although layers of history may remain underneath. 
Orban, Clara. "Contextualizing History in Hungarian Films of the New Millennium.” Hungarian Cultural Studies. e-Journal of the American Hungarian Educators Association, Volume 6 (2013): http://ahea.pitt.edu DOI:

Several recent Hungarian films present their narratives in ahistorical timeframes. These films seem to purposefully eliminate references that might contextualize them historically. In some ways, they truly have brought an end to history, but in reality the viewer transposes historical contexts to these films nonetheless. Béla Tarr's award winning Werckmeister Harmonies shows how the unknown, the magical, can spark philosophical discourse (implied in the title) but also bring chaos within an archetypal, ahistorical context. The film, which lacks what András Bálint Kovács calls "historical or geographical coordinates," is also Tarr's one film that makes references to military power and social unrest $(2013,131)$. The viewer is therefore led to extrapolate from this context to the historical context in which the film was produced. The end of communism brought Hungarians long-awaited freedom, and attention rightly focused on the positive gains of liberation. Still, it also left many bewildered at how to adapt to new expectations. In some ways, Tarr explores the difficulties of freedom for a people no longer accustomed to it. Bálint Kovács notes that in Werkmeister Harmonies, more so than in other Tarr films, the feeling of "no way out" is related to a subjective feeling, and the process of destruction so common in his films is here linked directly to the illusion of a superior spirit (2008). He notes that Tarr's films from this more recent period offer a complex vision of the historical situation in the Eastern European region thus underscoring that, despite an absence of diegetic historical elements, this film could be read as an allegory of millennial historical events.

Werckmeister Harmonies exhibits many of the characteristic traits of Tarr's cinema. It takes place in a village made timeless because neither the buildings nor the costumes can be attributed to a specific period. The only real indicator that the film takes place in the twentieth or twenty-first century is the presence of machines such as tanks, stoves, and tractors. There are no allusions to specific, recognizable historical personages or events. The title involves the most important philosophical musing of the film, a philosophical treatise on music. Mr. Eszter, an intellectual, withdrawn from the political upheaval around him, tapes a lecture on musical harmony. He notes that the Greeks accepted the imperfection of their instruments and thus only utilized a few notesperfect harmony was the province of the gods. Instead Andreas Werckmeister falsified the system to include all natural harmonies - but by doing so, he sacrificed some higher tones. Music and harmony, therefore, are based on deceptive foundations.

The main character, János, also known as Valuska, the town everyman, wanders throughout the village on his mail route as the viewer is introduced to a growing sense of unease. He stages a total eclipse in a bar with the help of patrons showing them how darkness can overtake light. Meanwhile "Aunt" Tunde, Eszter's ex-wife, and her lover the police chief talk of restoring order through a political takeover. The prince, a shadowy figure, comes to town in a seedy circus which also features a dead whale. Both the prince and the whale prove unsettling as the sense of dread grows. The dead whale arrives in a corrugated crate and lies in the center of town where patrons pay to enter the stinking container. At one point, Valuska suggests the whale is a sign of God's omnipotence. The whale thus evokes the creature in Moby Dick or the beached sea animal at the end of Fellini's La Dolce Vita, both allegorical figures suggesting the presence of God. In Werckmeister Harmonies, we learn that the prince has been rousing the populace to violence in other towns. The prince's followers ransack the town's hospital, stopping only when confronted by an old naked man in a tub, a sort of filmic "memento mori." After attempting to escape and being captured, Valuska goes to an asylum. Only Mr. Eszter survives intact, going to contemplate the whale in the town square as fog closes in to engulf the film's final scene.

The central metaphor of the film suggests that universal harmonies are out of tune. We search for perfection but, as musical principles show, slight disharmony is all we can achieve. 
Orban, Clara. "Contextualizing History in Hungarian Films of the New Millennium.” Hungarian Cultural Studies. e-Journal of the American Hungarian Educators Association, Volume 6 (2013): http://ahea.pitt.edu DOI:

Disharmony is linked in this film also to authority. The arrival of a political figure, the prince, brings random violence and unrest. Since his disembodied voice urges his followers to violence, the prince becomes a magic figure in the film, never seen but heard. The whale suggests contemplation of a higher philosophical meaning. Its presence in town excites but seems always out of place: characters express their fear of it. The film's end leaves open the fate of the town and characters. Mr. Eszter leaves Valuska in the hospital to examine the whale, now out of its container, in the town square. The film dissociates plot and character from identifiable historical moments in a failed search for an ideal, made impossible because of human imperfection that leads to Valuska' ultimate madness. The postman's optimism led him to organize his neighbors into staging the planets and their orbits, predictable, logical, soothing, yet invisible realities. Instead, these harmonious orbits cannot be sustained in the face of chaos, and the result is madness. In this film, violence may be a by-product of de-historicization. Markers such as the whale invite allegorical interpretation of this film as a reading of millennial Hungarian history. History retreats from the film's narrative but we are left with traces of a post-millennial malaise. Sandwiched between the optimism of the end of communism and reintegration into Europe, Tarr's film suggests that the impulse for political unrest is always with us because perfect harmony in unattainable.

Kontroll, the first film by Nimród Antal, is tightly-paced with gripping action reminiscent of horror films. Antal remains obsessed with the camera eye: cameras spy on us everywhere in the subway as killers watch what we do. Critics have dubbed Kontroll a satire, an allegory, a horror/suspense film, and even a hallucination. A ragtag group of inspectors on the Budapest subway system, the ticket control agents, patrol for scofflaws, often to humorous effect. We follow their daily encounters with the public and with each other in the desperate world under the city streets. To complicate matters, there is a killer in the subway system pushing unsuspecting passengers onto the tracks as oncoming trains arrive. Initially, these deaths are considered suicides until their numbers increase. Besides their daily routines, the ticket inspectors are now asked to look out for the "jumpers." In an early scene, the protagonist Bulcsu's team of inspectors-all on probation-share breakfast. They note that daily violent encounters lead to violent behavior.

Bulcsu was formerly a star architect who left his job to live in the subway. Instead of creating buildings that rise above ground, he lives below ground to battle his sense of inadequacy at not having been the best. Two figures live in the subway: Bulcsu and the black-hooded murderer. Ultimately, Bulcsu finds the killer at the metro party - a magical masked ball in the lower depths of the subway - and leads him on a "railing" challenge (where two runners navigate the tracks between two stations just ahead of the last train of the night, the "midnight express," that stops only at the end of the line). Throughout, the one shining figure in Kontroll is the girl in the bear costume, train conductor Béla's daughter. Sofi is dressed like a teddy bear for work, and rides the subway daily without paying her fare. At the end of the film she is dressed as a fairy at the masked ball. In the film's final scene, she leads Bulcsu up the escalator, the first time in the film he has left the subway.

Allegorical interpretations of Kontroll are suggested through various filmic strategies. Bulcsu and the subway murderer, for example, are the only two who live exclusively in the subway. These two characters represent the confrontation of good and evil, as the film constantly suggests its Manichean, at times Dantean, overtones (the underworld of the subway and the hellish punishments meted to the control agents by recalcitrant rider remind us of Dante's Inferno). In a strange way, the film often seems like it is in black and white. The opening sequence presents a subway system representative stating that this symbolic film about universal themes should not be construed as a critique of the Budapest subway. This disclaimer leads the viewer precisely towards allegorical readings which are supported by the film's lighting, characters and narrative. Good and evil collide 
Orban, Clara. "Contextualizing History in Hungarian Films of the New Millennium.” Hungarian Cultural Studies. e-Journal of the American Hungarian Educators Association, Volume 6 (2013): http://ahea.pitt.edu DOI:

in this ahistorical world. The inspectors (in effect powerless and their disaffection indicates they know it), must enforce orders given from uninspiring authority figures. People from all walks of life try to thwart authority, and some resort to violence as they resist paying the subway fare. This underground universe of darkness is a world of only illusory order.

Kontroll's narrative clearly takes place in a recent historical context given characters' costumes and mannerisms; however, there are no identifiable historical references that can specify a historical moment for the viewer. Since the film is entirely shot in the subway, we do not see any physical landmarks that might lead the viewer to contextualize the action in a historical timeframe. Within the subway, there are no newspapers, televisions, radio broadcasts or posters that allude to events or that show dates, places or names. Characters develop, or more precisely stagnate, in this menacing world divorced from real events. They live in the perpetual cycle of disdain for authority that wears the ticket collectors down until they become animal-like automatons.

The search for an impossible ideal, being the best architect, becomes so overwhelming that Bulcsu lets himself fall into the sort of madness subway life engenders. At the end, Bulcsu may reclaim his heritage as he goes towards the light but it is uncertain whether he will again be defeated in his search for an ideal. Whatever his outcome, and Antal does not suggest what it will be, Bulcsu's search for an ideal in an ahistorical present leads him to develop as a character and perhaps regain the humanity he lost in this urban underworld. Like a gender-reversed Orpheus and Eurydice, Sofi takes Bulcsu back to the light from this hell under ground. This film presents an allegory of the historical struggle between the willing abandonment of culture to primal instincts.

Steve Jobbitt notes that while Antal never intended Kontroll to be about Hungary per se, as the filmmaker stressed in interviews, the film nevertheless lends itself to metaphorical analysis. Jobbitt understands the film as a primarily male fantasy of integration and redemption, the same impulse that resonates through millennial Hungarian politics with Hungary's re-integration into the European Union. These impulses that "guided liberal-democrats in Hungary over the course of nearly two decades proved to be as much a burden as they had a promise" (Jobbitt, 2008). A historically identifiable framework has been replaced with an allegory of the loss of order and the danger to those who seek perfection, and to be the best. They may succumb to the dark side the subway represents. As was the case with Werkmeister Harmonies, Kontroll's ahistoricism encourages viewers to provide a contextualizing framework for the film. Perhaps Antal suggests that the optimism of the years before and after the arrival of the millennium should be tempered with realistic expectations of the potential for disorder and chaos, always just below the surface.

The new millennium provided a context of liberation from decades of domination and the hope of reinvigorated connections within the center of Europe. Loss and uncertainty, however, accompanied and tempered the optimism as Hungary moved from a regimented existence to the context of freedom and the responsibilities it entails. History, always of great import in Hungarian cinema, continued to provide a way to explore this new reality. Films provided a medium for showing how historical moments are muted through human experiences. Painful historical realities retreat as artistic constructs replace historical events. History at times disappears from films, replaced with allegorical structures that obscure, but indexically point to, the extra-diegetic contexts of the films. History may have indeed come to an end, replaced by uncertainty and warnings that optimism should be cautious at best. As Hungary has lurched from one societal transition to another, Hungarian filmmakers have kept their lenses firmly trained on how these transitions affect the nation and its people. 


\section{Works Cited}

Bálint Kovács, András. 2008. "The World According to Béla Tarr.” Kinokultura, Special Issue no. 7: Hungarian Cinema (February) http://www.kinokultura.com/specials/7/kovacs.shtml.

. 2013. The Cinema of Béla Tarr: The Circle Closes. New York: Columbia University Press.

Cunningham, John. 2004. Hungarian Cinema from Coffee House to Multiplex. London and New York: Wallflower Press.

Fukiyama, Francis. 1992. The End of History and the Last Man. New York: The Free Press. Hának, Péter. 2005. "Discontinuous History, Deformed Society." Journal of Popular Culture 29, no. 2 (1995): 58. As quoted in Melinda Szaloky, "Somewhere in Europe. Exile and Orphanage in Post-World War II Hungarian Cinema": 8. (in East European Cinemas, Edited by Anikó Imre, Something and London: Routledge. 81-102).

Jobbitt, Steve. 2008. "Nimród Antal's Kontroll—Subterranean Dreaming: Hungarian Fantasies of European Integration and Redemption" Kinokultura, Special Issue no. 7: Hungarian Cinema (February) http://www.kinokultura.com/specials/7/kontroll.shtml.

Portuges, Catherine. 2005. "Traumatic Memory, Jewish Identity.” In East European Cinemas. Edited by Anikó Imre. London: Routledge. 121-132. . 2007. "Central European Twins. Psychoanalysis and Cinema in Ildikó Enyedi's My Twentieth Century." Psychoanalytic Inquiry: A Topical Journal for Mental Health Professionals. 27:4. 525-539.

. 2013. "Memory and Reinvention in Post-Socialist Hungarian Cinema." In Cinemas in Transition in Central and Eastern Europe After 1989. Edited by Peter Hames and Catherine Portuges. Philadelphia: Temple University Press. 104-134. 